\title{
Schoolmaster's Empire: Race, Conquest, and the Centralization of Common Schooling in California, 1848-1879
}

\section{Matthew Gardner Kelly}

\begin{abstract}
This article explores how education reformers in California pioneered forms of centralized educational governance between 1850 and 1879. Challenging previous scholarship that has attributed the success of this early educational state to reformer Fohn Swett and New England migrants, this article situates the creation of common schools in California within the larger context of American state-building in the nineteenthcentury West. While increased state authority over education was a goal for reformers across the nation, this article contends that California's early innovations in centralization reflected a regionally specific response to the dilemmas of governing a recently acquired territory distant from eastern centers of power. The precarious nature of elite attempts to convert California into an American place, reflected in perceived lawlessness, weak governmental authority, and racial anxiety, inspired forms of educational organization commonly associated with Progressive Era responses to industrialization, urbanization, and immigration. The desire to promote nineteenth-century American racial and governmental order in California, this article concludes, powerfully shaped the growth of public education in the state, influencing the organization of schooling in ways that suggest the importance of looking beyond the Northeast to understand the development of public education in the United States.
\end{abstract}

In the 1960s, David Tyack criticized historians of education for failing to consider the nuance and complexity of American public education's spread across the continent. Many educational historians, he pointed out, have conflated Massachusetts and New York with the entire

\footnotetext{
Matthew Gardner Kelly is a doctoral candidate in History and Education at Stanford University. He would like to thank David Labaree, Leah Gordon, the participants in Gordon Chang's America and the World seminar, two anonymous reviewers, and the editors of HEQ for their help in improving this article.
} 
nation. ${ }^{1}$ Half a century later, it's not always clear that much has changed. When historians consider the development of public education in the United States, they rarely venture west of the Mississippi. ${ }^{2}$ When they do discuss the growth of public schooling in the American West, historians tend to suggest that the region played a minor role in its own development. Focusing on the influence of New England migrants on the creation of schools in the West, most historians understate the influence of regional differences on the system these migrants created, framing western schooling as a merely derivative enterprise. ${ }^{3}$

The nature of state-building in places like California, however, ensured that public schooling in the American West was never simply derivative. In California, early American school leaders embraced centralized educational governance before many eastern states and cities. During the 1850 s and 1860 s, state-level reformers streamlined teacher training and certification, required the completion of increasingly detailed paperwork, centralized the selection of textbooks, mandated a uniform course of study, and dictated a complex of rules and regulations for the operation of distant schools. By the 1870s, editors of leading eastern educational journals were highlighting California's

${ }^{1}$ David Tyack, "The Kingdom of God and the Common School: Protestant Ministers and the Educational Awakening in the West," Harvard Educational Review 36, no. 4 (December 1966): 447-69.

${ }^{2}$ Most histories of the common school movement concentrate their analysis on the Northeast. See Lawrence Cremin, The American Common School: An Historic Conception (New York: Teachers College Press, 1951); Michael B. Katz, The Irony of Early School Reform: Educational Innovation in Mid-Nineteenth Century Massachusetts (New York: Teachers College Press, 2001); Michael B. Katz, Reconstructing American Education (Cambridge, MA: Harvard University Press, 1987); Carl Kaestle, Pillars of the Republic: Common Schools and American Society, 1780-1860 (New York: Hill and Wang, 1983); and William Reese, America's Public Schools: From the Common School to No Child Left Bebind (Baltimore: Johns Hopkins University Press, 2005). For two accounts that challenge the tendency for educational historians to focus exclusively on New England, see Joseph W. Newman, "Antebellum School Reform in the Port Cities of the Deep South," in Southern Cities, Southern Schools: Public Education in the Urban South, ed. David N. Plank and Rick Ginsberg (New York: Greenwood Press, 1990), 17-36; and Tyack, "The Kingdom of God and the Common School."

${ }^{3}$ In the context of California, several historians invoke this logic by emphasizing the New England origins of the fourth superintendent of instruction in the state and attributing the development of education in California to his New England pedigree. See Roy W. Cloud, Education in California: Leaders, Organizations, and Accomplishments of the First Hundred Years (Stanford, CA: Stanford University Press, 1952), 39; Nicholas C. Polos, "A Yankee Patriot: John Swett, the Horace Mann of the Pacific," History of Education Quarterly 4, no. 1 (March 1964): 17-32; and Kevin Starr, Americans and the California Dream, 1850-1915 (New York: Oxford University Press, 1973), 87-88. Other histories emphasize the "New England" origins of early school promoters in general. See, for example, Irving G. Hendrick, California Education: A Brief History (San Francisco: Boyd \& Fraser, 1980), 6. Both views are problematic, given the presence of numerous reformers from southern states and the opposition of some New England migrants to educational expansion. 
uniquely aggressive state role in public schooling. An 1873 article in the National Teacher, for example, described the "California experiment," marveling at efforts by reformers to prescribe a uniform course of study across the state. ${ }^{4}$ By the 1870 s, reformer John Swett boasted that California was far more centralized than eastern states in matters of teacher certification, insisting that "Yankeedom is, in respect to State legislation concerning professional certificates, just about where the colonies were A.D. 1775." ${ }^{5}$ In this western state, education reformers were often leading, not following, their eastern counterparts.

California's early innovations in state educational centralization represented a regionally specific response to the dilemmas of American state-building in a newly acquired, multiracial space. As Patricia Limerick reminds us, "Conquest was far more than a simple political and legal transaction." ${ }^{6}$ While the military campaign to take California concluded in 1848, American leaders continued to pursue the political and cultural conquest of the region long after. As a state function, public education in California developed while an emerging elite ambitiously sought, often unsuccessfully, to impose the structures of American government and culture on the newly acquired region. ${ }^{7}$ In their attempts to impose an elusive order through schooling, early state leaders sought to make California an unquestionably American space. The imperatives of conquest on the fringes of America's landed empire, as much as a Wiebeian "search for order" that paralleled eastern developments, shaped the evolution of public education in nineteenth-century California. ${ }^{8}$

Race was at the center of common schooling and state formation in the early years of American occupation. According to elites in the region, imposing American racial hierarchies onto California was necessary for the state's successful integration into the national fabric. Through the rigid maintenance of segregated schooling and the separation of "white" and "nonwhite" students, early school leaders sought to make California an American place. Segregated schooling,

4"The California Experiment," National Teacher: A Monthly Educational Fournal 3, no. 6 (June 1873): 226.

5ohn Swett, "An Outsider's View of It," clipping from "Some of my Articles as The Pacific Coast Editor of the New England Journal of Education," carton 2, John Swett Papers MSS C-B 352 (hereafter JSP), Bancroft Library, University of California, Berkeley.

${ }^{6}$ Patricia Nelson Limerick, The Legacy of Conquest: The Unbroken Past of the American West (New York: W. W. Norton, 1987), 236.

${ }^{7}$ On the efforts of elites to impose American gender and racial hierarchies onto San Francisco through "cultural frontiers" like restaurants, hotels, boardinghouses, tourist attractions, fairs, and expositions, see Barbara Berglund, Making San Francisco American: Cultural Frontiers in the Urban West, 1846-1906 (Lawrence: University of Kansas Press, 2007). 1967).

${ }^{8}$ Robert H. Wiebe, The Search for Order, 1877-1920 (New York: Hill and Wang, 
in the words of one commentator, would allow California to practice the "secret of Britain's success as a colonizing power," preventing the creation of a "mongrel race of moral and mental hybrids" and ensuring the success of American state-building along the Pacific coast. ${ }^{9}$

The precise boundaries of whiteness, however, were contested. Throughout the 1850s and 1860s, a series of local controversies concerning the classification of "white" pupils with "colored parents" convinced state leaders that only a strong and uniquely centralized state educational system could clarify racial boundaries, guarantee the maintenance of segregated schooling, and ensure the larger success of American state-building in the region. The political power and racial status of native Californio populations in southern California aggravated concerns about local control and enhanced the appeal of a strong educational state. With the 1848 treaty of Guadalupe Hidalgo classifying Californio children as white, state leaders insisted that the former residents of Mexican California must attend common schools in preparation for American citizenship. At the same time, however, the state's former rulers were considered "half civilized," and local control would thus place educational decisions into the hands of a group that occupied, in the words of one historian, an "ambiguous position" in California's emerging racial hierarchy. ${ }^{10}$ In response to these tensions around racial boundaries and related concerns with perceived lawlessness and weak governmental authority, educational leaders in California embraced uniquely aggressive forms of state control over public education. ${ }^{11}$

While increased state authority over education was a goal for common school reformers across the nation, most historians associate the successful centralization of educational governance at the state level with a Progressive Era response to industrialization, urbanization, and immigration. According to this narrative, the bureaucratization of $1858,2$.

9 "The Public Schools and Colored Children," San Francisco Bulletin, 24 February

${ }^{10}$ On the unique nature of race relations and the ambiguous status of Californios, see Tomás Almaguer, Racial Fault Lines: The Historical Origins of White Supremacy in California (Berkeley: University of California Press, 1994) and D. Michael Bottoms, An Aristocracy of Color: Race and Reconstruction in California and the West, 1850-1890 (Norman: University of Oklahoma Press, 2013), 82.

${ }^{11}$ On perceptions of antebellum California as lawless, see Woodrow James Hansen, The Search for Authority in California (Oakland, CA: Biobooks, 1960); Roger D. McGrath, "A Violent Birth: Disorder, Crime, and Law Enforcement, 1849-1890," in Taming the Elephant: Politics, Government, and Law in Pioneer California, ed. John F. Burns and Richard J. Orsi (Berkeley: University of California Press, 2003), 27-73; and Kevin J. Mullen, Let Fustice Be Done: Crime and Politics in Early San Francisco (Reno: University of Nevada Press, 1989). On connections between California's racial diversity and perceptions of the region as disorderly, see Almaguer, Racial Fault Lines, and Berglund, Making San Francisco American. On the fluidity of racial and gender hierarchies within the mines, see Susan Lee Johnson, Roaring Camp: The Social World of the California Gold Rush (New York: W. W. Norton, 2000). 
schooling started in the nation's cities following the Civil War. After World War I, these reforms spread from cities to rural communities, empowering state governments and challenging an esteemed American tradition of "democratic localism." 12 California followed a much more complicated and divergent path. Not only did early school reformers in the region embrace this aggressive state role early and for different reasons, Californians also decentralized their school system at the precise moment that reforms encouraging centralization and uniformity were beginning to succeed in other regions. Placing explicit legal limits on the ability of the state to "interfere" with distant schools, teachers, and children, leaders at California's second constitutional convention "democratized" the state's school system in $1879 .{ }^{13}$

When historians have discussed early education in California, they have tended to focus on "Yankee migrant" John Swett's tenure as the first Republican superintendent of public instruction during the Civil War. ${ }^{14}$ While John Swett was a crucial figure in California's early centralization, his party affiliation and New England pedigree

${ }^{12}$ For accounts of Progressive Era education reforms designed to encourage centralization, see Lawrence A. Cremin, The Transformation of the School: Progressivism in American Education, 1876-1957 (New York: Alfred A. Knopf, 1961); Michael Katz, Class, Bureaucracy, and Schools: The Illusion of Educational Change in America (New York: Praeger, 1975); David B. Tyack, The One Best System: A History of American Urban Education (Cambridge, MA: Harvard University Press, 1974); William A. Bullough, Cities and Schools in the Gilded Age: The Evolution of an Urban Institution (Port Washington, NY: Kennikat Press, 1974); Raymond E. Callahan, Education and the Cult of Efficiency: A Study of the Social Forces That Have Shaped the Administration of Public Schools (Chicago: University of Chicago Press, 1962); and Tracy Lynn Steffes, School, Society \& State: A New Education to Govern Modern America, 1890-1940 (Chicago: University of Chicago Press, 2012).

${ }^{13}$ Hendrick, California Education, 19.

${ }^{14}$ For histories of California education, most of which tend to perpetuate this view, see William G. Carr, John Swett: The Biography of an Educational Pioneer (Santa Ana, CA: Fine Arts Press, 1933); William W. Ferrier, Ninety Years of Education in California, 1846-1936:A Presentation of Educational Movements and Their Outcome in Education Today (Berkeley, CA: Sather Gate Book Shop, 1937); Leighton H. Johnson, Development of the Central State Agency for Public Education in California, 1849-1949 (Albuquerque: University of New Mexico Press, 1952); Cloud, Education in California; and Nicholas C. Polos, Fohn Swett: California's Frontier Schoolmaster (Washington, DC: University Press of America, 1978). Hendrick, Tyack, James, and Benavot provide more sophisticated accounts that, nonetheless, elevate Swett above his predecessors and tend to dismiss continuities between early superintendents. See Hendrick, California Education; Irving G. Hendrick, "From Indifference to Imperative Duty: Educating Children in Early California," California History 79, no. 2 (July 2000): 226-49; and David Tyack, Thomas James, and Aaron Benavot, Law and the Shaping of Public Education, 1785-1954 (Madison: University of Wisconsin Press, 1987), 87-107. The best histories of education in California have focused on gender and race. See, for example, Charles $M$. Wollenberg, All Deliberate Speed: Segregation and Exclusion in California Schools, $1855-$ 1975 (Berkeley: University of California Press, 1976); Irving G. Hendrick, The Education of Non-Whites in California, 1849-1970 (San Francisco: R \& E Research Associates, 1977); Victor Low, The Unimpressible Race: A Century of Educational Struggle by the Chinese in San Francisco (San Francisco: East/West Publishing, 1982); and Kathleen Weiler, Country Schoolwomen: Teaching in Rural California, 1850-1950 (Stanford, CA: Stanford University 
alone do not explain the trajectory of educational development in the state. The perception of governmental and racial disorder, rather than regional or political allegiance, united the architects of California's early educational state.

This article focuses on state-level discourse and policy related to education and state authority during the period of California's first state constitution, and spotlights the administrations of the first four superintendents to understand how the perception of racial and governmental disorder shaped the development of public education in California. While this article often provides a view from the top, it is also recognizes how, despite the grand visions and imperial dreams of these reformers, attempts to exercise new forms of state authority through schooling were always limited. In fact, many centralizing reforms were developed in response to the failure of previous assertions of state control, particularly in relation to school segregation. On paper, the system developed by these reformers was powerful and distinct. In reality, the authority of this system was, like early American government in the region, fragile and contested. It proved difficult to make laws stronger merely by passing more of them. In the end, the case of early schooling in California is not a story of social control, but a clear demonstration of the limits of top-down educational reforms and attempts by the state, through schooling, to shape its residents.

\section{A Government, and System, in Name Only}

On February 2, 1848, Upper California and New Mexico were formally ceded to the United States, the newest acquisitions in America's landed empire. Despite the firm grasp implied by military victory, and the image of authority conjured by the presence of an occupying army, actual control over the region was precarious at best, nonexistent at worst. As Neal Harlow explains, American government in California "lacked the pervasiveness and persuasiveness of collective self-government, yet had not sufficient force to compel obedience." ${ }^{15}$ Robert Semple openly doubted the legitimacy of the American military, editorializing that "the power of our present military governor was at least very questionable."16 Violence was rampant, especially among the thousands of miners who flocked to the region in search of gold. "Murder," one historian of

Press, 1998). On the history of higher education in California, see John A. Douglass, The California Idea and American Higher Education (Stanford, CA: Stanford University Press, 2000).

${ }^{15}$ Neal Harlow, California Conquered: The Annexation of a Mexican Province, 18461850 (Berkeley: University of California Press, 1982), 318.

${ }^{16}$ Quoted in Hansen, The Search for Authority in California, 86. 
California explains, "became a way of life." ${ }^{17}$ Within this politically and socially fluid environment, American conquest seemed incomplete. Fearful that the meager governmental structures would completely dissolve, military governor Bennet C. Riley, without the legal authority to do so, called for the election of delegates to a constitutional convention. In the fall of 1849 , forty-eight men gathered in Monterey, hoping to write a series of words that would transform into a government with legitimacy, authority, and power.

Many of these delegates believed that schooling was necessary for the region's conversion into an American state. The first provision of Article IX of the California constitution, calling for the creation of a constitutional officer to direct a system of public education, was approved without debate. The final section, dealing with the creation of a higher education system, was adopted on similar terms. Even debates over educational provision reflected consensus. Delegates who opposed elements of the amendment nonetheless maintained that public education was necessary. There was strategy behind the convention's adoption of educational provisions. In drawing heavily from the constitution of Iowa, the Union's newest state, delegates sought legitimacy. Some scholars have also asserted that these former residents of eastern states were simply trying to re-create familiar institutions, essentially "importing" the common school. ${ }^{18}$ There is some truth to this assertion, though it is important to remember that common schools were not universally accepted during the period. ${ }^{19}$ Most southern states continued to oppose state-sponsored and publicly funded systems of education, and seventeen of the California delegates, including the most vocal supporters of liberal educational provisions, came from these states. As John Douglass points out, "No legal or moral mandate dictated that a public system of education be established in California." 20 The idea that migrants from New England were simply re-creating familiar institutions in the region, then, fails to explain the enthusiasm for schooling among some delegates.

While the system outlined in Monterey was sketched in words borrowed from Iowa, delegates insisted that schooling was uniquely important for California because it would tame the place and consolidate American governmental authority. Semple, the southern convention president, dismissed the "fanatics ... on the subject of education"

\footnotetext{
${ }^{17}$ Starr, Americans and the California Dream, 55.

${ }^{18}$ See, for example, Hendrick, California Education, 6-16.

${ }^{19} \mathrm{On}$ the composition of the constitutional convention, see Harlow, California Conquered, 339. For a discussion of the limited growth of common schooling in the antebellum South, see Kaestle, Pillars of the Republic, 182-217.

${ }^{20}$ Douglass, The California Idea and American Higher Education, 23.
} 
back east. However, Semple argued that an expansive system of public schooling was "a subject of peculiar importance here in California, from our location and the circumstances under which we are placed." 21 This uniqueness required a "liberal and permanent fund" for the support of public schools. ${ }^{22}$ M. M. McCarver developed a similar theme, insisting that "nothing will have a greater tendency to secure prosperity to the State, stability to our institutions, and an enlightened state of society, than by providing for the education of our posterity." ${ }^{23}$ In the "Address to the People of California," delegates highlighted the "peculiar circumstances in which California becomes a State-with an unexampled increase of a population coming from every part of the world, speaking various languages, and imbued with different feelings and prejudices."24 Further, the delegates explained, the presence of "natives of Old Spain, Californians, and those who have voluntarily relinquished the rights of Mexicans to enjoy those of American citizens" made California a unique context. Amidst the contestations over governmental authority, schools were essential institutions that promised to give American laws the kind of power they seemed to lack. "A knowledge of the laws - their moral force and efficacy, thus becomes an essential element of freedom, and makes public education of primary importance," the delegates concluded. ${ }^{25}$

\section{John Gage Marvin: Forging a Paper Bureaucracy}

The document produced in Monterey was accepted by the U.S. Congress and, following the Compromise of 1850, the former Mexican province was admitted to the Union as a free state. Cultural and political conquest, however, remained incomplete. Governmental authority was tenuous. The migration of young men in search of gold undermined attempts to create stability and integrate California into the national fabric. As Anne F. Hyde explains, the gold rush "created acute and fatal conditions for creating order" in California. ${ }^{26}$ For John Gage Marvin, the state's first superintendent of public instruction, schooling represented an antidote to this disorder. A Democrat from Pennsylvania,

${ }^{21}$ Report of the Debates in the Convention of California on the Formation of the State Constitution: in September and October 1849 (Washington, DC: J. T. Towers, 1850), 204.

22 "Address to the People of California" in John T. Frost, History of the State of California. From the Period of the Conquest by Spain, to Her Occupation by the United States of America (New York: Miller, Orton, 1857), 424.

${ }^{23}$ Debates in the Convention of California, 204-205.

24"Address to the People of California," 424.

${ }^{25}$ Ibid., 423-24.

${ }^{26}$ Anne F. Hyde, Empires, Nations, \& Families: A History of the North American West, 1800-1860 (Lincoln: University of Nebraska Press, 2011), 435. 
Marvin was nominated for the office by a group of miners in Tuolumne County. Elected in October 1850, he found that the constitutional provisions for education lacked power, and he ambitiously sought to transform Article IX's words into a powerful and highly centralized system of schooling. While legislators concerned with limited financial resources resisted some of Marvin's proposed reforms, he managed to persuade lawmakers to accept elements of a strong state role in education. Marvin, moreover, imagined and described public schooling as essential for converting California into an American place, further refining an emerging regional discourse about the role of public schooling in consolidating American power in the region.

In response to the continued instability of American state-building in California, Marvin advocated the creation of a highly centralized and hierarchically organized system of schooling. In his proposed 1851 school law, Marvin insisted that the state superintendent, rather than local communities, should control finances and have direct supervisory powers over schools. ${ }^{27}$ Through the creation of county directors responsible to the state superintendent, Marvin envisioned a hierarchically organized bureaucracy where county officers would collect statistics, disburse funds, evaluate local educators to determine their moral and mental fitness for teaching, and represent teachers in disputes with local officials. ${ }^{28}$ While the legislature initially rejected Marvin's vision, in 1852 legislators passed a school law accepting elements of it, providing the foundations for what would later become California's uniquely centralized system. ${ }^{29}$ In addition to creating a school board composed of the governor, superintendent, and state surveyor, this new law granted the superintendent direct supervisory power over high schools, normal schools, and teacher institutes across the state. ${ }^{30}$ Further, the law created two new officers in each county, the school census marshal and the county superintendent, both of whom would report directly to Marvin and provide "suitable instructions and forms for the direction" of all educational employees. ${ }^{31}$ Though locally elected, these

${ }^{27}$ David F. Ferris, Fudge Marvin and the Founding of the California Public School System (Berkeley: University of California Press, 1962), 56.

${ }^{28}$ For the political significance of quantification, see Theodore M. Porter, Trust in Numbers: The Pursuit of Objectivity in Science and Public Life (Princeton, NJ: Princeton University Press, 1995); and Ferris, Fudge Marvin, 60.

${ }^{29}$ Quoted in Ferris, 7udge Marvin, 60.

${ }^{30}$ John Gage Marvin, An Act to Establish a System of Common Schools in the State of California and Other Acts Providing for the Revenue of the Same, with Explanatory Forms (Sacramento: Printed at the Democratic State Journal Office, 1852), 9.

${ }^{31}$ Ibid., 2. 
intermediary actors were subject to state oversight and required to "distribute promptly" all "blank Reports, Forms, Laws, and instructions." 32

To enhance the enforcement power of the nascent system, the distribution of finances was made contingent on compliance with state regulations. ${ }^{33}$ Adding particular authority to the system, each census marshal was to be selected from a pool of existing constables. These officers were required, in turn, to personally count each child in the state and gather statistics for the state superintendent. The execution of their duties would ostensibly produce encounters between every child and the state, in addition to making the population legible to administrative control. ${ }^{34}$

To gather support, Marvin emphasized the importance of schooling for the larger, often precarious project of converting California into an American place. While his focus on centralized educational governance resonated with the work of eastern reformers advocating the creation of early urban school bureaucracies, Marvin insisted that his system was tailored to the unique requirements of state-building in California. Marvin acknowledged that education "has engaged the attentive thought and pens" of such luminaries as Horace Mann, but he rejected the notion that the educational systems of eastern states or European nations could be re-created in California. A "system of Schools in California like our laws," Marvin wrote, "will necessarily differ in several respect[s] from those of France, Prussia, or those of the sister States." 35 California's location "on the shores of the Pacific," a great distance from eastern centers of power, necessitated immediate action to create a robust system of schooling. Without a new school law, he insisted, "permanent settlement and consequent prosperity" would slow. ${ }^{36}$

Essential to the transformation of California into an American place was the conversion of its former rulers into citizens. According to many early school officials, the expansion of the common school was essential for native Californio communities. While considered white by the California constitution, native Californios occupied a racially

${ }^{32}$ Ibid., 5. Simply by having the law printed and distributed, Marvin hoped to enhance the power of the legislature's enactment. He had learned from experience. The 1851 law had never been printed, making enforcement impossible.

${ }^{33}$ Ibid., vi.

${ }^{34}$ Ibid., 2. On the importance and limitations of legibility for state power, see James C. Scott, Seeing Like a State: How Certain Schemes to Improve the Human Condition Have Failed (New Haven, CT: Yale University Press, 1998).

35 "Report of the Superintendent of Public Instruction," John G. Marvin letters and memorandum, 1851-1854, reel 2, (hereafter JGM), Bancroft Library, University of California, Berkeley.

${ }^{36}$ Ibid. 
ambiguous position in the minds of many Anglo elites. ${ }^{37}$ For Marvin, the presence of native Californios in the southern portion of the state made the emerging state's educational needs all the more urgent. Many children in the state, he warned the legislature, were children of "the older Californians." Among the "five to eight thousand persons ... . between the ages of four and eighteen," he exclaimed, a quarter were Spanish-speaking and "have little or no education beyond that of repeating, and a few reading the ceremonies and religious books of the Catholic Church." 38 "This class of our population," Marvin continued, would willingly attend American schools, if enough were created. ${ }^{39}$

Early county superintendents reinforced Marvin's logic. The superintendent of Los Angeles County, for example, warned state officials that the county had the "materials ... for the worst banditti in the world - the uneducated boys and young men of native stock." At the same time, the superintendent explained, "they can be gathered and taught the virtues and knowledge of Americans too." ${ }^{40}$ Imagining that California's former rulers had both a natural propensity for crime and the potential for redemption through assimilation, early educational leaders in the state presented the common school as a powerful tool for addressing the ambiguous position of native Californios and integrating them into a new American state.

Despite the seemingly hierarchal nature of the system outlined in the 1852 law, it existed more on paper than reality. In a technical oversight, the law failed to formally create county superintendents, though it prescribed the office's substantive duties. Marvin requested new legislation to create the nonexistent office, which the legislature eventually granted. ${ }^{41}$ Nevertheless, Marvin feared that county agents would ignore their responsibilities, rendering their role ineffective. Sacramento and San Joaquin counties refused to file their reports, an act of defiance that Marvin could not control. The bureaucracy Marvin imagined was overextended, an ambitious ideological projection that was materially unreal.

\footnotetext{
${ }^{37}$ Almaguer, Racial Fault Lines, 45-74.

38 "Report of the Superintendent of Public Instruction,"JGM.

${ }^{39}$ To support the expansion of schooling in the state, Marvin sought to incorporate parochial schools into the system by providing state funding to religious schools. Between 1853 and 1855 , the state school law allowed religious schools to receive public school money. For more on this early aid to religious schools in California, see Paul Goda, "The Historical Background of California's Constitutional Provisions Prohibiting Aid to Sectarian Schools," California Historical Society Quarterly 46, no. 2 (June 1967): 149-71.

${ }^{40}$ Eleventh Annual Report of the Superintendent of Public Instruction (San Francisco: Benjamin P. Avery, State Printer, 1862), 56-57.

${ }^{41}$ Ferris, Fudge Marvin, 88.
} 


\section{Paul Hubbs: Racial Segregation and the Problem of Local Control}

Perhaps nothing better illustrates the centrality of race to state centralization in California than the changing opinion of the state's next superintendent, Paul Hubbs. The centralized forms of state authority Marvin favored were not universally accepted, and Hubbs initially opposed the expansion of state control over local schools. However, reacting to the inextricable connections between common schooling and the pursuit of racial order, Hubbs shifted his position in 1855 when local control threatened segregation. ${ }^{42}$

In his early reports to the legislature, Hubbs proposed an alternative education system that would empower local communities. According to the new superintendent, the paper bureaucracy Marvin forged was needlessly complicated and ineffective. ${ }^{43}$ In January 1855 , Hubbs recommended getting rid of county superintendents. ${ }^{44}$ According to Hubbs, local school trustees, rather than intermediary officials responsible to the state, should direct educational decision making. He reiterated his concerns about centralized authority in a later report, proposing that the "law be so modified as that the common schools be managed by the people of the school district," rather than the state. ${ }^{45}$

Despite his initial commitment to local control, however, Hubbs embraced centralization and state authority when local communities disregarded elite visions of American racial categories. In March 1855, the superintendent received a letter from a local school trustee in the mining town of Grass Valley, inquiring whether schools where "colored and white children mix as scholars" were entitled to state funds. ${ }^{46}$ Without directly stating that schools in Grass Valley were integrated, the trustee wondered if state funds would be jeopardized by the presence of nonwhite children. Hubbs' faith in localized educational governance was pushed to a breaking point, and he responded to the letter publicly. "I had not supposed it necessary to give any instruction upon this subject," Hubbs wrote, "believing that the good sense of the Commissioners, gentlemen who, in general, are highly esteemed for their intelligence and careful discretion in the exercise of their important

\footnotetext{
${ }^{42}$ Ibid., 102.

${ }^{43}$ Fifth Annual Report of the Superintendent of Public Instruction of the State of California (Sacramento, CA: James Allen, State Printer, 1856), 3.

${ }^{44}$ Fourth Annual Report of the Superintendent of Public Instruction of the State of California (Sacramento, CA: B.B. Redding, State Printer, 1855), 4.

${ }^{45}$ Fifth Annual Report, 8. $1855,2$.

46"Shall Negroes Go to School?” The Nevada fournal [Nevada City, CA], 6 April
} 
duties, did not require it." 47 Hubbs claimed to "have no antagonism to the education of the negro, the mongrel, and all the other races of man." 48 Nonetheless, he wrote, "I maintain the opinion that the law in relation to public schools applies to those only who are capacitated (as the Californians and the Americans are) to become citizens of the republic." 49 Hubbs also asserted the power of his office in a form that contradicted his emphasis on local control: "Whenever there is presented proper evidence to this department that the officers of any school have intermingled negro children with the white, I shall deem it my duty to the parents and to the children, to the success of our public school system, and to the present and future good of our country, to rule out such school from the public schools of the State." ${ }^{50}$ For Hubbs, it was the duty of the state to maintain racial purity in the schools, for schools were indispensable sites in maintaining the racial hierarchies that would ensure California's transformation into an American place.

The incident in Grass Valley highlighted the limitations of the superintendent's authority, and Hubbs responded by enhancing the power of the state. Despite his strong language, Hubbs had no legal authority to defund the Grass Valley schools and no clear method for determining whether or not the schools were actually integrated. This is perhaps best reflected in the closing statement of his open letter, where he asked the school trustee to please "advise me of the immediate cause of your categorical inquiry." ${ }^{11}$ Through the legislative process, however, Hubbs passed a revised school law that inserted the word white into the school code, connecting funding to the number of "white" children in a region, rather than the number of children overall. ${ }^{52}$ This move functioned, in turn, to extend the legibility project pursued by the state. With the insertion of the word white, census marshals throughout the state were now required not only to individually count California's children but also to classify their race and determine their eligibility for state school funds. If properly implemented, every child in California would now be both personally visited and racially classified by a representative of the state. The revised 1855 school law also sought to regulate Californio and Mexican communities in the southern

${ }^{47}$ Paul K. Hubbs, "Letter from the Superintendent of Public Instruction," Sacramento Daily Union, 27 March 1855, 2.

${ }^{48}$ Ibid.

${ }^{49}$ Ibid.

${ }^{50}$ Ibid.

${ }^{51}$ Ibid.

${ }^{52}$ Ibid. 
portion of the state, requiring that all instruction within public schools be conducted in English. ${ }^{53}$

Even with these changes, however, the power of the superintendent to regulate race and language in distant schools was limited. ${ }^{54}$ In Santa Barbara, public instruction in Spanish remained available throughout the 1850s. ${ }^{55}$ In Los Angeles, the town council appropriated public funds for Antonio Jimeno del Recio to teach Mexican and Californio children in Spanish, despite the provisions of the new law. ${ }^{56}$

According to some observers, the issue in Grass Valley was not that children of color were admitted to the school; the issue centered on the precise definition of whiteness. The supervisors in Grass Valley had discovered that "three of the white children had colored parents," but since they were "white," they had been allowed to attend the schools. ${ }^{57}$ When challenged for admitting the students, the school trustees insisted that "there were no colored children in the school, and that they intended to keep all the children there." ${ }^{" 58}$ E. A. Tompkins, the Grass Valley school trustee, stated that he expelled the children "suspected of being tainted with Indian or negro blood," though he insisted that they were "as white as many others not suspected of any such taint." 59 Another observer suggested that the trustees completely ignored Hubbs, never expelling the students in question. ${ }^{60}$ As Barbara Berglund points out, defining the boundaries of whiteness in the region reflected "an

${ }^{53}$ The 1855 school law also outlawed aid to religious schools, which would have prevented Californio and Mexican children from receiving public support for instruction in Spanish. In 1855, the legislature also overturned the requirement that all laws be published in Spanish. For a discussion of the revised 1855 school law and its implications for Latino communities in Southern California, see Victoria-Maria MacDonald, Latino Education in the United States: A Narrated History from 1513-2000 (New York: Palgrave Macmillan, 2004), 63-66.

54 "Shall Negroes Go to School?"

${ }^{55}$ Before 1855, instruction in Santa Barbara was only available in Spanish. After the passage of the 1855 law, two Anglo school commissioners joined forces with the editors of the Santa Barbara Gazette to advocate English-language instruction in the public schools. While an English-only school was created in 1855, instruction in Spanish remained available. For financial reasons, the English and Spanish classes were combined, and many Anglo families removed their children from the public schools until English instruction was again offered in 1858. See Albert Camarillo, Chicanos in a Changing Society: From Mexican Pueblos to American Barrios in Santa Barbara and Southern California, 1848-1930 (Cambridge, MA: Harvard University Press, 1979), 17-18.

${ }^{56}$ For the controversies surrounding English instruction in American public schools in Los Angeles, see Leonard Pitt, The Decline of the Californios: A Social History of the Spanish-Speaking Californians, 1846-1890 (Berkeley: University of California Press, 1970), 224-28.

${ }^{57}$ J. Holland Townsend, "American Caste and Common Schools," Anglo-African Magazine I (March 1859), 81.

58 "Shall Negroes Go to School?"

${ }^{59}$ Ibid.

${ }^{60}$ Townsend, "American Caste and Common Schools," 81. 
ongoing process of incorporation and hierarchy-building with its genesis in the imperial impulse." 61 The next superintendent would continue this process, attempting to further Americanize California by maintaining racially segregated schools. Moreover, he would do so by expanding California's emerging educational state.

\section{Andrew Jackson Moulder: Imperial Dreams and Racial Fantasies}

The state's next superintendent, Andrew Jackson Moulder, also believed that common schooling would promote political, social, and racial order in rough-and-tumble California. ${ }^{62}$ While his concern for order occasionally paralleled eastern versions of nineteenth-century educational utopianism, Moulder also expanded a regionally specific vision of common schooling that emphasized connections between successful state-building, centralization, and the maintenance of American racial categories in California. ${ }^{63}$ According to Moulder and his allies, "success as a colonizing power" was determined by the "integrity of the white race." ${ }^{64}$ Racial mixing in the state's schools, they reasoned, would be fatal for the integration of California into the nation. As new controversies emerged about the boundaries of whiteness, Moulder increasingly sought to persuade the legislature that this mixing could only be prevented by creating a strong state educational bureaucracy.

Though California had been an American state for six years when Moulder assumed office, governmental authority remained precarious, especially amidst the perceived chaos of the Second Committee of Vigilance in San Francisco. According to Governor John Neely Johnson, the city existed in "a state of insurrection," prompting the state's chief executive to impose martial law. ${ }^{65}$ For six months, in the words of David Alan Johnson, "the [second vigilance] committee governed the city according to its own reckoning." ${ }^{66}$ Regardless of whether the vigilance

${ }^{61}$ Berglund, Making San Francisco American, 8.

${ }^{62}$ Planning to migrate north to Washington Territory, Paul Hubbs declined renomination at the next Democratic Party Convention. In his place, delegates nominated former San Francisco city controller and southerner Andrew Jackson Moulder. While Democratic control of state government was challenged the previous year when the Know-Nothing Party assumed power over the governorship and legislative assembly, Moulder was victorious in the 1856 election. "Democratic State Convention Third Day," Sacramento Daily Union, 12 September 1856, 2. For more on the California KnowNothing Party, see David Alan Johnson, Founding the Far West: California, Oregon, and Nevada, 1840-1890 (Berkeley: University of California Press, 1992), 199-202.

${ }^{63}$ For a discussion of eastern common school reform rhetoric that focused on the role of early public education in fighting crime, see Kaestle, Pillars of the Republic, 33, 36; and Katz, Reconstructing American Education, 16-24.

64"The Public Schools and Colored Children."

${ }^{65}$ Johnson, Founding the Far West, 201.

${ }^{66}$ Ibid. 
committee is framed as a reaction to, or an example of, lawlessness and corruption, their deeds paint a picture of tenuous state control. California, in the words of historian Kevin Starr, remained "volatile, uncertain, a continuing question." ${ }^{67}$

Throughout his writings, Moulder framed schooling as the antidote to this lawlessness. An expansive system of public education, he insisted, would cure the "evils" facing the state. ${ }^{68}$ Developing an argument common among eastern reformers, Moulder also claimed that the state would save money by investing in schools, since it would lower the cost of maintaining prisons ${ }^{69}$ In an 1858 document designed to instruct local school officials about their legal requirements, Moulder included sixty-five "thought-springs," quotations from educational leaders in eastern states. "All School Officers in California, Teachers and parents, are earnestly solicited, not simply to read, but to ponder them," he wrote. ${ }^{70}$ Of these sixty-five thought-springs, only one references the role of education in citizenship and republican governance. ${ }^{71}$ Instead, most quotations discuss connections between education and the maintenance of social order, with titles like "Education Diminishes Pauperism and Crime," "Education and Crime," "The Prison and the School," "What Criminal Statistics Show," "The Germ of Crime," and "How Education Diminishes Crime."72 For Moulder, public schooling would promote governmental stability, not by producing virtuous republicans, but by curbing rampant crime and violence.

While Moulder's focus on education and crime seemed to parallel eastern discussion about school reform, Moulder also emphasized the contingency of California's status and ascribed to education an invaluable role in securing American conquest. "Above all other states in the Union," Moulder insisted, California required a military-style university. ${ }^{73}$ This type of university, he argued, was required due to California's insecure conquest:

We are far removed from the seat of the general government, and in time of foreign war or rebellion, must rely, in a great measure upon ourselves.... It

${ }^{67}$ Kevin Starr, California: A History (New York: Modern Library, 2005), 106.

${ }^{68}$ Eighth Annual Report of the Superintendent of Public Instruction (Sacramento, CA: Charles T. Botts, State Printer, 1859), 4.

${ }^{69}$ Ibid., 4-5.

${ }^{70}$ Andrew J. Moulder, Commentaries on the School Law, with the Elements of School Architecture. Laws Relating to the School Lands. Forms and Instructions. (Sacramento, CA: John O'Meara, State Printer, 1858), 103.

${ }^{71}$ Ibid., 115 .

${ }^{72}$ Ibid., 108, 110, 113-14, 116.

${ }^{73}$ Seventh Annual Report of the Superintendent of Public Instruction (Sacramento, CA: John O'Meara, State Printer, 1859), 10. 
is to continue the supply of such soldiers through the next generation, that I urge the military system of education. ${ }^{74}$

While Moulder acknowledged that the federal government would send troops in the event of foreign invasion, he also emphasized the idea that California's status was insecure. He even sought to convince legislators that California might leave the Union and that, in this event, public schooling would be particularly important for "the establishment of an independent republic upon our coast." 75

While crime and distance from the East seemed to threaten American state-building along the Pacific coast, for Moulder and his allies nothing threatened the American conquest of California more than the intermingling of races in the region's schools. In order to impose a distinctly American social order on California, Moulder and his supporters expected schools to maintain "racial purity." However, another incident involving divergent definitions of whiteness threatened this project, again highlighting the imprecision of racial categories and the problem of local educational control in California. In 1858, another seemingly "white" student was discovered to have "colored parents." The student, Sarah Lester, was attending San Francisco High School. After the editors of the San Francisco Herald exposed the student, the San Francisco School Board was pressured to act. While the board accepted segregation in principle, some officials wanted Lester to stay at the school because of her academic success and the fact that she "so closely resembles a white person." 76 One trustee even proposed that local authorities should have the power to make exceptions in "cases where the white blood predominates."77

According to many observers, allowing Lester into San Francisco's public schools was dangerous not only because it created a precedent for other African-American families in San Francisco, but also because it encouraged California's other "inferior races" to seek access to the "white" public schools. According to the editors of the San Francisco Bulletin, for example, the incident violated the need to maintain the separation between all the "white and inferior races in our State." The editors of the Daily Alta California expressed a similar sentiment, contending that an exception for Lester would only "open the door to additional trouble of a like nature." ${ }^{78}$ Some commentators associated

\footnotetext{
${ }^{74}$ Ibid.

${ }^{75}$ Ibid.

76"Negroes in the Public Schools," San Francisco Daily Globe, 10 February 1858, 2. ${ }^{77} \mathrm{Ibid}$.

78"Colored Children in Public Schools," Daily Alta California, 20 February
} 1858, 1. 
"amalgamation" in schools with the potential failure of an American colonial project in California:

\begin{abstract}
Philosophers and political economists have often puzzled themselves to arrive at the secret of Britain's success as a colonizing power-for while the colonies planted by France and Spain languish and decay, those planted by England flourish and grow into vast empires and nationalities. But few writers attribute this to the real cause, which is, the preservation in its integrity of the white race.... We want no mongrel race of moral and mental hybrids to people the mountains and valleys of California. ${ }^{79}$
\end{abstract}

Moulder shared these ideological conceptions about the maintenance of racial order through schooling, and he used the incident to illustrate the need for the legislature to enhance the power of his office. In January 1859, Moulder framed the incidents in Grass Valley and San Francisco as part of a statewide pattern where local communities defied state mandates and allowed "the children of Negroes into our Public Schools on an equality with the Whites." 80 Moulder claimed to be helpless in the face of these incidences and after he "employed all the power conferred upon him by law" told the legislature that he was unable to stop integration. ${ }^{81}$ According to Moulder, allowing black and white children to attend the same schools would destroy public education. Residents, Moulder claimed, would abandon the schools rather than "permit their daughters-fifteen, sixteen, and seventeen years of age- to affiliate with the sons of Negroes." ${ }^{\prime 2}$ Moulder, like other observers, connected the mixing of black and white students with the integration of all of California's "inferior races." "If this attempt to force Africans, Chinese, and Diggers, into our white Schools is persisted in," he warned, "it must result in the ruin of our Schools." 83

In viewing common schools as an important force for converting California into an American place, Moulder and his peers sought a careful balance, contending that both the education of "inferior races" and the preservation of exclusively white schools were necessary for American state-building in the region to succeed. Following the Lester incident, most newspaper editors were careful to concede that if there were to be nonwhites in California, they must be educated. The editors of the San Francisco Bulletin explained, for example, "If we must have negroes and Chinamen among us it is better, of course, if they are

\footnotetext{
79 "The Public Schools and Colored Children."

${ }^{80}$ Eighth Annual Report, 14.

${ }^{81}$ Ibid., $14-15$.

${ }^{82}$ Ibid., 15.

${ }^{83}$ Diggers was a slur Americans used to describe California's indigenous peoples.
} Eighth Annual Report, 14. 
educated." However, they argued that education must be segregated to "preserve our Caucasian blood pure." 84

Similarly, Moulder argued that segregated schools should be made available to students who did not qualify for the white school. "It is not desirable," Moulder explained to the legislature, that these students "be brought up in ignorance and heathenism." 85

To ensure that education would fulfill its role in preventing crime, securing conquest, and maintaining racial purity in California, Moulder advocated expanding state authority over local districts. To begin, Moulder attempted to convert local officers into obedient bureaucrats. The state education system employed 2,162 individuals, and Moulder believed that each of them should be accountable to the state:

Connected with the Department of Instruction, and in constant communication with its head, are four hundred and eleven school Marshals, four-hundred and thirty-two Teachers, twelve-hundred and thirty-three Trustees, forty-three County Superintendents and forty-three County Treasurers. ${ }^{86}$

For Moulder, the problem was that these officers were not under the control of the department's head. He lamented, "Either through ignorance or indifference, many of these officers have, in former years, performed their duties in a very spiritless and unsatisfactory manner." 87 To render the officers responsive to his authority, Moulder distributed a document entitled Commentaries on the School Law. Published in 1858, 1860 , and 1862, this pamphlet contained explicit directions to school officers. It also included the new, increasingly detailed forms Moulder created. Reflecting on the first edition, Moulder told the legislature that he was "much gratified" by the "very marked improvement already exhibited in the performance of their duty." 88 Within the nearly twohundred-page document, he prescribed a host of responsibilities, many of which were not technically required by law.

For Moulder, county superintendents would increase the state's influence over communities. Moulder instructed county superintendents to "visit the several Schools in their counties, not simply once, but repeatedly, during the year." ${ }^{89}$ This, Moulder believed, would allow the state to better influence the behavior of teachers. ${ }^{90}$ Moulder also believed county superintendents should support local compliance. County

\footnotetext{
84"The Public Schools and Colored Children."

${ }^{85}$ Eighth Annual Report, 14.

${ }^{86}$ Ibid., 8.

${ }^{87} \mathrm{Ibid}$.

${ }^{88}$ Ibid.

${ }^{89}$ Moulder, Commentaries on the School Law, 9.

${ }^{90}$ Ibid.
} 
superintendents, he explained, "should not fail to enforce upon the several School Officers the necessity of making, not simply a skeleton, but a full report, and promptly." 11

Information was crucial for Moulder, making children and schools legible to the state and providing data that could be leveraged to determine and enforce influential new policies. The forms Moulder created "to secure uniformity" radically increased the amount of information the state was able to gather. While in the past, Moulder explained in a report to the legislature, county superintendents only "furnished but a barren array of figures," they were now required to record:

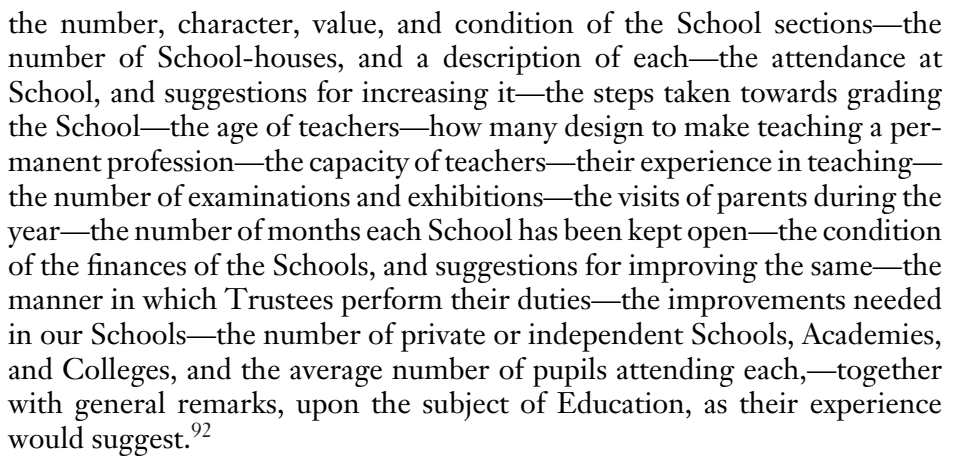

In addition, Moulder provided each county superintendent a "blank note book, with appropriate headings and instructions" to support information gathering. ${ }^{93}$

State information gathering could only be accomplished if local communities complied, and Moulder underscored the consequences of noncompliance. Failure to completely and accurately submit reports, he reminded officials, was grounds for a "total loss of any share of the School Fund." ${ }^{94}$ In situations where schools complied with the law but failed to submit reports on time, they should still be denied funds. To compel compliance, Moulder suggested that census marshals be paid per "schoolable child." This, Moulder insisted, made it the interest of every marshal to "seek out and return the name of every child, no matter at how great a distance from the beaten road its parents may reside." ${ }^{95} \mathrm{Fi}-$ nally, Moulder explained that an "active, energetic discharge" of county

${ }^{91}$ Ibid., 10.

${ }^{92}$ Eighth Annual Report, 4.

${ }^{93}$ Moulder, Commentaries on the School Law, 64.

${ }^{94}$ Ibid., 10 .

95 "School Matters," clipping from scrapbook vol. 4, n.d., n.p., Andrew Jackson Moulder Papers MSS C-B 526 (hereafter AMP), Bancroft Library, University of California, Berkeley. 
superintendents' duties would "furnish the strongest argument for an increase of their compensation." 96 Money would grease the wheels of California's redemption through centralized schooling.

Moulder also sought to increase the authority of the state by centralizing teacher certification-removing power from local trustees and enabling the state to determine who can teach. Moulder's representation of district trustees demonstrated his intense distrust of local authority. "In many, probably in most instances, the Trustees are not competent for this duty," he explained. ${ }^{97}$ In a later report, he similarly disparaged their fitness to make decisions. ${ }^{98}$ Here, Moulder won a partial victory. In the revised school law passed in 1860, "Trustees were relieved of the duty of examining those proposing to become Teachers, and of granting them certificates." 99 Local communities would no longer determine who would teach their children.

Given the enforcement power that Moulder sought to derive from state funds, it should be no surprise that he advocated state control of school finance. Slowly, towns were beginning to sell township lands donated by the federal government. Moulder was concerned about the impact of locally controlled funds, and he repeatedly requested that the legislature empower the state to control any profits generated from such transactions. ${ }^{100}$ Otherwise, he argued, local control of finance would produce unequal school funding.

Similarly, Moulder sought to control curriculum, aspiring to have the state determine what children in distant schools were taught. With the passage of a new school law in 1860, the board of education was granted authority to "fix upon a uniform system of textbooks." ${ }^{101}$ However, months later, the legislature repealed the law, believing it was "susceptible to abuse" and "arbitrary." 102 In response, Moulder wrote that "the restoration of the law repealed will meet the approval of a large majority of the Teachers and parents, who are the chief sufferers from the changes so constantly made." 103 For Moulder, the state should determine what is taught, not local communities.

Despite Moulder's imperial visions, the forms of control he sought never materialized. Census marshals neglected their duties. Most census

${ }^{96}$ Moulder, Commentaries on the School Law, 65.

${ }^{97}$ Eighth Annual Report, 11.

${ }^{98}$ Ninth Annual Report of the Superintendent of Public Instruction (Sacramento, CA: Charles T. Botts, State Printer, 1860), 6.

${ }_{99}$ Tenth Annual Report of the Superintendent of Public Instruction (Sacramento, CA: Charles T. Botts, State Printer, 1861), 9.

${ }^{100}$ Seventh Annual Report, 8.

${ }^{101}$ Eleventh Annual Report of the Superintendent of Public Instruction (Sacramento, CA: Benjamin P. Avery, State Printer, 1862), 24.

${ }^{102}$ Ibid., 25.

${ }^{103}$ Ibid. 
reports were either incorrect or purposefully misleading. "The Census Marshal, sworn officer though he be, has forged some of the children, and is endeavoring to palm off dummies or rag babies upon me as bona fide flesh and blood," Moulder complained. ${ }^{104}$ If the multiple copies of haphazardly filed and half-blank forms from the Benicia school district are any indication, local trustees simply ignored Moulder's move toward centralization. ${ }^{105}$ In attempting to combat disorder through educational bureaucracy, Moulder simply created more opportunities for disobedience as local officials ignored his new laws.

\section{John Swett and California's Education State}

While the power of educational bureaucracy in California remained limited, reformers continued to increase state control over education throughout the 1860s. Historians have tended to attribute California's aggressive state role in educational matters to the influence of John Swett and the Republican Party, but his innovations as superintendent were extensions of previous reforms. Throughout his tenure, Swett not only extended the project of centralization initiated during the 1850 s, but employed a similar rhetoric as his predecessors, contending that the expansion of state control over education would impose order on wild and woolly California, making it an American place. This promise became particularly salient when the Civil War injected even more uncertainty into the American nation-building project in the state. The imperatives of conquest and disunion, California's educational leaders suggested, would be effectively managed by a robust and powerful educational state.

While the California state elections of 1862 were bitterly contested, debates over the superintendent's office reflected common ground shared by state Democrats and Republicans on the relationship between American state-building and race. Amidst the uncertainty of the Civil War, the new Union Fusion Party nominated John Swett for superintendent in July, with Andrew Jackson Moulder temporarily retiring from politics. ${ }^{106}$ California Democrats accused Swett of admitting nonwhite children into the Rincon School while he was principal, circulating thousands of handbills portraying "a Yankee schoolmaster teaching a mixed class of whites and blacks, with a little Negro boy

104"The Trials and Tribulations of a School Officer-No. 3," clipping from vol. 4, n.d., n.p., AMP.

${ }^{105}$ For several examples, see Benicia School Board Records, BANC MSS C-A 147, box 1 , folders 6-9.

${ }^{106}$ Cloud, Education in California, 39. Moulder would later serve on the Board of Regents for the University of California and as superintendent of San Francisco schools. 
at the head of the class."107 "The question therefore is," Henry Janes, a critic of Swett, wrote in a separate pamphlet, "are the people of California prepared to endorse this monstrous doctrine, by their votes at the coming election." 108 Swett vehemently denied the claim that he had integrated the school, contending that a separate official accidently admitted some "very light mulatto girls" and that, upon learning that the students were not actually white, had them removed. ${ }^{109}$ In their messages to the public, both Republicans and Democrats insisted they would maintain racially segregated schools. Despite the public outcry, voters generally distrusted Democrats and elected Swett. The Shasta Courier, for example, wrote that "John Swett should be elected because by education and profession he is fitted ... and because California is an unconditionally loyal state and his opponents are mainly disloyal men." 110

Swett, like his predecessors, emphasized the role of schooling in settling the region. At the dedication of School House Number 1 in San Francisco, Swett gave a speech describing the purposes of public education:

This house should be consecrated to the spirit of order. An efficient discipline is essential to the existence of the public schools.... The importance of strict government must be admitted by all. ${ }^{111}$

In his emphasis on "the spirit of order" and the "importance of strict governance," Swett drew on familiar themes. The superintendent frequently employed martial metaphors to articulate the role of schooling in an ongoing process of conquest in the West. Unity and central organization, Swett maintained, were crucial. In organizing against "ignorance and vice," he wrote, educators must together pursue "regular warfare and drilled columns."112

In his public writings, Swett emphasized the role of schooling in imposing an American social order on the region. According to Swett, eastern educational practices were insufficient. "The routine of the schools in the old cities of the East," Swett wrote, "is not adapted to our bustling community, we must frame our system to meet the wants

${ }^{107}$ Polos, "A Yankee Patriot," 21.

108 "Have Negroes Been Taught and Classed on Terms of Equality in a Public School Under the Charge of Mr. John Swett," n.d., portfolio, Research Materials Related to John Swett MSS 84/176 c, Bancroft Library, University of California, Berkeley.

109 "Statement of Fohn Swett," Sacramento Daily Union, 20 September 1862, 3.

${ }^{110}$ Quoted in Polos "A Yankee Patriot," 21.

${ }^{111}$ Clipping from Rincon School Scrapbook, p. 9, n.d., carton 2, JSP.

112 "Normal Classes for Teachers," clipping from Collection of Prose Scrapbook, n.d., p. 26, carton 2, JSP. 
of the times." 113 California, Swett explained, required a different kind of public schooling:

Life here is intense; thought is intensified; action is energetic; schools must be practical.... Fellow teachers! We are the Pioneer teachers of the Pacific. Let the system we shall settle on these schools be a life-giving system. ${ }^{114}$

In his first report to the legislature, Swett further developed this theme. "If one state in the union needs a system of free schools more than any other, that State is California," Swett declared. Diversity, he continued, made the creation of this system particularly important. "Her population is drawn from all nations," Swett explained. According to the superintendent, "The next generation will be a composite one, made up of the heterogeneous atoms of all nationalities. Nothing can Americanize these chaotic elements and breathe into them the spirit of our institutions but the public schools." 115 For Swett, like Moulder, for schooling to Americanize the region it had to occupy a careful balance, maintaining American racial hierarchies by segregating schools while ensuring, simultaneously, that all students were educated enough to prevent crime and disorder. In the same report, Swett explained that "children of all classes, whether white, black, tawney, or coppercolored" must be educated. ${ }^{116}$ This education, however, had to occur in "separate schools." 117 Through a precarious mix of compulsion, exclusion, and segregation, Swett imagined the common school instilling order in California.

The Civil War figured prominently in Swett's rhetoric, representing a further threat to authority and stability in California. Swett attributed rebellion to the absence of public education in southern states, and highlighted the importance of schooling for national government. ${ }^{118}$ "You will never make California union to the backbone," Swett warned the legislature, "until you have a school system so thorough that all the people shall be brought into the schools and thoroughly Americanized." 119 Without an extensive state system, Swett insisted that the

${ }^{113}$ Ibid.

${ }^{114}$ Ibid.

${ }^{115}$ First Biennial Report of the Superintendent of Public Instruction of the State of California, for the School Years 1864 and 1865 (Sacramento, CA: O. M. Clayes, State Printer, 1866), 272.

${ }^{116}$ Ibid., 57.

${ }^{117}$ Ibid.

${ }^{118}$ At the conclusion of the conflict, Swett claimed that he had "looked after both sides impartially." Quoted in Polos "A Yankee Patriot," 24.

${ }^{119}$ Union Party, California, Proceedings of the Union State Convention, held at Sacramento on the 17th and 18th Days of June, 1862 (San Francisco: Eastman and Godfrey Printers, 1862), 16. 
diverse population of California would tear California away from the Union. Drawing on this rhetoric, Swett played a pivotal role persuading the legislature to increase state authority over education with the passage of the 1864 and 1866 school laws.

While extensions of an ongoing process, the 1864 and 1866 school laws attracted national attention. Historians have called them "the most comprehensive schools bills of the nineteenth century." 120 Henry Barnard's education journal described the 1866 law as "a noble contribution to the interests of national education" and argued that it "laid our whole country under lasting obligation." 121 Though part of a coherent project first pursued by Marvin, Hubbs, and Moulder, the laws were transformative nonetheless.

The 1864 and 1866 school laws dramatically increased state authority over what was taught in California. Fulfilling an agenda originally pursued by earlier superintendents, the new school laws mandated the adoption of state-approved textbooks and a uniform course of study. Every school in the state was required to study physiology, U.S. history, and physical education. Specific textbooks, selected for their ideological implications, were dictated for use across the schools. For example, Swett selected M. F. Cowdery's Elementary Moral Lessons because he thought the text enforced "habits of personal cleanliness, neatness in dress, order, obedience, and politeness" through "simple stories" that "illustrate the virtues of honesty, truthfulness, and kindness to one another, and to animals." 122 In addition, the new school laws further centralized teacher certification, increasing state control over who could teach. Both laws extended previous reforms, increasing the role of the education department in training and certifying teachers. Licensing requirements were increased, state allocations for teacher training expanded, and the State Board of Education assumed greater responsibility for certification. ${ }^{123}$

The state also adopted a series of rules and regulations that would reflect increasingly minute forms of control over teachers and students. These regulations covered a host of behaviors, from the requirement that "vocal and breathing exercises be conducted at least twice a day" for five minutes, to the regulation that teachers "prevent all quarreling and disagreement, all rude and noisy behavior in the streets, and vulgar and profane language" among students "going to, and returning from,

${ }^{120}$ Tyack et al., Law and the Shaping of Public Education, 93.

121 "Public Instruction in California," American Fournal of Education 16 (December 1866): 634.

${ }^{122}$ Department of Public Instruction, Revised School Law: Approved March 24, 1866 (Sacramento, CA: O. M. Clayes, State Printer, 1866), 48.

${ }^{123}$ Tyack et al. Law and the Shaping of Public Education, 93. 
school." 124 The uniform course of study was equally specific, not simply dictating what textbooks should be used, but bow teaching should take place. During reading lessons, for example, a "drill of two minutes" was required daily. Teachers were required to explicitly teach comportment by "explaining and enforcing habits of personal cleanliness, neatness of dress, order, obedience, and politeness." 125

According to Swett, these reforms would enable new forms of control over children. At times, Swett distrusted parents, insisting that teachers are "superior to the parent in point of authority." 126 The new course of study, he wrote, allowed the state to "pursue an intelligent system of instruction, in spite of prejudices of parents who are too ignorant to comprehend the purposes of school." 127 The education department in Sacramento would dictate what children throughout the state were taught. Extending a project started in the 1850s, Swett further expanded the paper and imperial bureaucracy imagined by his predecessors. The state, through schooling, aspired to exercise increasingly novel forms of influence over distant schools, teachers, and children.

These new forms of control could not succeed, however, if they only reached a select group of children. In an effort to bring all children under the influence of the common school, Swett's new legislation sought to expand segregated schooling in the state. The 1864 law established more "colored schools" in the state by requiring districts to create separate schools for "Negroes, Mongolians, and Indians" if more than ten "colored" children applied for entry to the public schools. As the United States entered Reconstruction and American race relations seemed poised to change, the 1866 law attempted to extend the common school even further, permitting districts with fewer than ten students deemed "nonwhite" to attend the white public schools if "parents of the children attending such schools make no objection in writing." 128 These provisions would later prove pivotal when African Americans in California challenged all forms of school segregation in the state, prompting the state supreme court to presage Plessy v. Ferguson by twenty-two years and establish the principle of "separate but equal" schooling in Ward v. Flood. ${ }^{129}$

${ }^{124}$ Cloud, Education in California, 255.

${ }^{125}$ Ibid., 42.

${ }^{126}$ Quoted in Zachary Montgomery, The Poison Fountain: or, Anti-Parental Education: Essays on the School Question From a Parental and Non-Sectarian Standpoint (San Francisco: published by the author, 1878), 15 .

${ }^{127} \mathrm{John}$ Swett, "Address of the Superintendent of Public Instruction of the State of California, Hon. John Swett, Before the State Teachers' Institute, Held in San Francisco, May 7th, 1867" (San Francisco: Towne \& Bacon, Book and Job Printers, 1867).

${ }^{128}$ Revised School Law, 18.

${ }^{129}$ Ward v. Flood, 48 Cal. 36 (1874) 


\section{Conclusion}

As it materialized, California's educational state became increasingly controversial in the 1870s. The Democratic newspaper Occidental and Vanguard in 1867 published a series of scathing editorials challenging Swett and state control over education. "The great radical wrong in the present common school system," the editors contended, is "that it subordinates the authority of the parent over his own child, to the authority of the State, and leaves the former powerless." ${ }^{130}$ The 1866 law allowing a potential degree of integration, along with the general association of state Republicans with Reconstruction, prompted voters to unseat most Republicans in the state and replace them with Democrats. ${ }^{131}$ While Swett's successors remained generally committed to centralized educational governance, some were more circumspect about state authority. Democrat O. P. Fitzgerald opposed compulsory school laws, describing such measures as "despotic."132

Throughout the 1870s, urban workers and rural farmers became increasingly critical of centralized state authority, corporate power, and political corruption. As Kevin Starr explains, the decade wrought on California "an unmitigated disaster." 133 In response, Californians voted to rewrite their state constitution. While the goals of the convention centered on corporate regulation, taxation, labor protections, and antiChinese provisions, the state education department also came under scrutiny. ${ }^{134}$ Amidst a general distrust of corruption and bureaucracy, convention delegates dismantled much of the state education department, shifting responsibility for schooling to local communities. The new constitution prohibited the legislature from passing laws interfering with "the management of local public schools." 135 Teacher certification was returned to county superintendents, and decision-making power over curriculum and textbook adoption was granted to local districts. As California entered the Progressive Era, state leaders sought to prevent the growth of state-level educational bureaucracy.

While short lived, the education system developed in California during the early years of American occupation suggests the importance of looking beyond the Northeast to understand the development of public education in the United States. The inextricable connections

${ }^{130}$ Quoted in Montgomery, The Poison Fountain, 141.

${ }^{131}$ Bottoms, An Aristocracy of Color, 112.

${ }^{132}$ Nevertheless, legislators managed to pass a compulsory school law in 1874 . For a discussion of the law's passage and its limited effectiveness, see Tyack et al., "Law and State School Policy"; "Annual Address of Superintendent Fitzgerald, State Teachers' Institute, Nov. 7, 1871," The California Teacher 9 (December 1871): 162.

${ }^{133}$ Starr, Americans and the California Dream, 132.

${ }^{134}$ John F. Burns, introduction to Taming the Elephant, 13.

${ }^{135}$ Hendrick, California Education, 19. 
between schooling and broader attempts to impose an American social, political, and cultural order on California demonstrates how school reform in the region was never an uncomplicated attempt to re-create eastern common schools along the Pacific coast, but a regionally specific response to the dilemmas of American state-building in a contested, multiracial space. While we usually associate state-level centralization with a Progressive Era response to industrialization, urbanization, and immigration, the case of California invites us to consider the limits of this explanatory framework. On the outer edge of the burgeoning American empire, moves toward the bureaucratic centralization of schooling were part of a precarious and contingent state-building project in recently acquired territory, a project that often centered on the creation of racial hierarches. Indeed, the management of racialized difference was essential to converting California from a Mexican province into an American state, and schooling was essential to that management. It was impossible to make a nineteenth-century American state without a dose of nineteenth-century racial anxiety, and we can't tell the history of America's educational past without considering the specter of empire that hangs over the nineteenth-century American West. 